\title{
UTILIZATION OF WATER YAM (Dioscorea alata) AS A SOURCE OF ETHANOL
}

\author{
A.M. Hashimi \\ Department of Chemical Sciences (Analytical Chemistry), Olabisi Onabanjo University, Ago-Iwoye, Ogun \\ State, Nigeria. \\ Author's E-mail: hashimi.adejumoke@oouagoiwoye.edu.ng,+2348054669153 \\ Received 17 September 2020; accepted 11 January 2021, published online 30 January 2021
}

\begin{abstract}
Ethanol $\left(\mathrm{C}_{2} \mathrm{H}_{5} \mathrm{OH}\right)$ is a primary alcohol which can be produced by fermentation, using any of the sources of carbohydrates such as sugarcane, cassava, grains and yam tubers among others. Production of ethanol fermented from renewable sources for fuel and fuel additives are known as bioethanol. Since the need of bioethanol is increasing, the production of bioethanol must be increased using cheaper and eco friendly raw materials. This study was conducted, using cheaper and eco friendly raw materials; water yam (Dioscorea alata) as alternative sources for ethanol production. The starch that was produced from water yam was hydrolysed into fermentable sugar, using acid hydrolysis. The fermentable sugar was converted into ethanol by fermentation process at $\mathrm{pH} 4.5$ using fermenting brewer's yeast (Saccharomyces calsbergensis). Starch, glucose and ethanol which were obtained were analysed for physicochemical properties. Findings revealed that the starch sample obtained gave a blue-black colouration on addition of few drops of iodine solution. This confirmed that the carbohydrate content was mainly starch. On calculation of viability, findings further showed that water yam is a good raw material for production of ethanol, therefore indigenous production of ethanol obtained from water yam is economically viable and recommended. This will save the country from lot of money spends annually on the importation of ethanol and it can also provide job opportunity for many wandering and unemployed Nigerians.
\end{abstract}

KEYWORDS: Ethanol, Water yam, Starch, Fermentation, Viability, Eco friendly.

\section{INTRODUCTION}

The largest single use of ethanol is as a motor fuel and fuel additive. It is also an important industrial ingredient and has widespread use as a base chemical for other organic compounds and used in medical wipes and most commonly as an antibacterial hand sanitizer gels for Corona virus and as an antiseptic [1]. Alcohol is an organic compound that has one or more hydroxyl $(\mathrm{OH})$ groups attached to a carbon atom. In dilute aqueous solution, it has a somewhat sweet flavor, but in more concentrated solutions it has a burning taste [2]. There are various types of alcohol but the common term used by wine makers is ethyl alcohol or ethanol $\left(\mathrm{C}_{2} \mathrm{H}_{5} \mathrm{OH}\right)$. Alcohol is classified into primary, secondary and tertiary. $\mathrm{C}_{2} \mathrm{H}_{5} \mathrm{OH}$ is a primary alcohol and it is the second member in the alcoholic series while methanol $\left(\mathrm{CH}_{3} \mathrm{OH}\right)$ called wood spirit is the first member of the series. Primary alcohol is oxidized with solution of potassium - (or sodium) dichromate (vi) or potassium manganate (vii) in dilute sulphuric acid to give aldehyde and with further oxidation will give a carboxylic acid. A secondary alcohol will on oxidation with solution of potassium - (or sodium) dichromate (vi) or potassium manganate (vii) in dilute sulphuric acid yields ketone; while tertiary alcohol is resistance to oxidation [3].

Ethanol is produced commercially by fermentation and/or synthetic process. The synthetic process involves direct hydration of ethene, indirect hydration of ethene and hydration of ethyne (acetylene) [4]. Fermentation is a term that has been applied to the decomposition of food stuffs and is one of the oldest techniques of food preservation. The best-known example is alcoholic fermentation in which sugar is converted into alcohol and carbondioxide using yeast as catalyst as given in the reaction equation (1).

$\mathrm{C}_{6} \mathrm{H}_{12} \mathrm{O}_{6}(\mathrm{aq}) \stackrel{\text { Yeast }}{\longrightarrow} 2 \mathrm{C}_{2} \mathrm{H}_{5} \mathrm{OH}(\mathrm{aq})+2 \mathrm{CO}_{2}(\mathrm{~g})$

The fundamental reaction underlying the production of ethanol by fermentation is the catalytic conversion of glucose into alcohol by the enzyme present in yeast [5]. It was Mitscherlich in 1841 who first demonstrated that fermentation occurred in sugar solution only after the introduction of live yeast cells. Any source of carbohydrates such as sugarcane, cassava, grains and yam tubers among others can be fermented for production of alcohol. The industrial production of ethanol 
utilizing ethene or acetylene is limited due to high cost of equipment and synthetic processes involved. The high demand for ethanol in diverse industries has necessitated research on alternative sources for ethanol production from low cost and readily available raw materials like water yam. This is with the view of making ethanol to be readily available and become more economically cheap for small and large-scale industries to patronize.

Yam plant is a deeply rooted climbing dioecious perennial vine with distinctively veined; cordate leaves and inconspicuous, monocotyledon flowers. The species most commonly cultivated is Water yam (Dioscorea alata), Chinese yam (Dioscorea esculenta), White yam (Dioscorea rotundata), Yellow yam (Dioscorea cayenensis). An 8 to 10 months growing session is required for a crop to mature, so that little opportunity for cultivation of yam exists outside the tropics. Yam has the following composition: Starch (21\%), Fat (1\%), Water (36\%), Protein (13\%), Mineral matter (2.5\%), Albuminoids (10\%).

\section{EXPERIMENTAL METHODS}

\section{Physicochemical Characterization of the Water yam Starch Sample \\ Determination of Moisture Content}

Cleaned petri dish was dried for 30 minutes in an oven at $104{ }^{\circ} \mathrm{C}$ and cooled in a dessicator. The petri dish was weighed and $10.0 \mathrm{~g}$ of milled water yam starch sample was weighed into it and placed in the oven at $105^{\circ} \mathrm{C}$. It was removed and cooled in the dessicator after heating for 2 hours. It was weighed and subsequently heated in the oven until constant mass was observed. Percentage (\%) moisture was calculated using the formula below.

$$
\% \text { moisture }=\frac{M_{o}-M_{1}}{M_{o}} \times 100
$$

where $M_{o}$ is the initial mass of the sample and $\mathrm{M}_{1}$ is the final mass of the sample

\section{Starch Test}

An amount of $0.4 \mathrm{~g}$ of the powdered water yam starch sample was dissolved in $5.00 \mathrm{~mL}$ of distilled water in a test tube. The solution gave a blue-black colouration on addition of few drops of iodine solution [6].

\section{Acid Hydrolysis}

\section{MATERIALS AND METHODS}

The water yam (Dioscorea alata) used for this study was purchased from the local market (Atikori) in Ijebu-Igbo, Ijebu North Local Government area of Ogun State, Nigeria. While the fermenting brewer's yeast (Saccharomyces calsbergensis) used was obtained from standard breweries, ImagbonIjebu. The starch was extracted using method by Adeyemi and Omotosho in extraction of starch from cocoyam. The yam was peeled, disintegrated into paste with grinder, extra water was added to the paste to obtain a slurry, which was left to stand overnight. The sediments were transferred into a Muslin cloth bag and pressed to obtain starch suspension, while the coarse residue was discarded. The starch suspension was left to stand for 24 hours. The supernatant was decanted and the starch resuspended in fresh water and left to stand overnight after which the starch was recovered. The starch was dried in the sun for two days with constant grinding of the crystal with a big spatula to obtain fine powder and sieved. This was kept in a corked bottle for use in the subsequent work in the laboratory

The method of Christopher Dumazert [7] was used for the acid hydrolysis. An amount of $50.0 \mathrm{~g}$ of the powdered form of the water yam starch was treated with $500 \mathrm{~mL}$ of $0.2 \mathrm{M} \mathrm{HCl}$ in a $1 \mathrm{~L}$ round bottom flask. The solution was heated under reflux for 3 hours [8]. The mixture was then cooled and filtered. The $\mathrm{pH}$ 1.6 obtained for the hydrolysed filtrate was increased to 4.7 with $0.5 \mathrm{M} \mathrm{NH}_{3}$ solution a slightly acidic state suitable for the action of fermenting microorganism [9].

\section{Determination of Reducing Sugar}

An amount of $5 \mathrm{~mL}$ of the hydrolysed filtrate was collected and analysed for the reducimg sugar content. A mixture of equal volume of Fehling`s solution A (Copper sulphate solution) and B (Sodium potassium tartrate and sodium hydroxide solution) was added to it in a conical flask [10]. The mixture was then heated at $90{ }^{\circ} \mathrm{C}$ for 5-15 minutes to develop a red-brown color. Concentration of reducing sugar $(\mathrm{g} / \mathrm{L})$ was calculated with the line equation of known glucose concentration [11]. 


\section{Fermentation Process}

The amount of $595 \mathrm{~mL}$ of the hydrolysed filtrate left after the test for reducing sugar content was used for fermentation. Fermenting brewer's yeast (Saccharomyces calsbergensis) cell was used to inoculate the hydrolysed filtrate. The fermentation was set up at room temperature for 5 days. The yeast suspension was removed after the fermentation process. The chemical equation for the fermentation reaction as given by [5]:

$\mathrm{C}_{6} \mathrm{H}_{12} \mathrm{O}_{6}(\mathrm{aq}) \frac{\text { Saccharomyces calsbergensis }}{\mathrm{pH} 4.7, \text { Temp. } 25^{\circ} \mathrm{C}}$
$2 \mathrm{C}_{2} \mathrm{H}_{5} \mathrm{OH}(\mathrm{aq})+2 \mathrm{CO}_{2}(\mathrm{~g})+$ Energy (heat)

\section{Distillation}

The clear solution obtained from the fermentation process was distilled to obtain the alcohol. In distilling, the fermented product was poured into a quick fit round bottom flask fitted with condenser. The ethanol was distilled using a sand bath at temperature of $(70-82)$ ${ }^{\circ} \mathrm{C}$ and the distillate was collected. The distillate liquor was redistilled for 2-3 times in order to increase the percentage purity of the ethanol.

\section{RESULTS AND DISCUSSION}

The Results obtained from the analysis carried out on the starch sample, fermentable sugar and ethanol obtained from the water yam (Dioscorea alata) samples are presented in Table1

\section{(a) Starch sample}

The starch samples obtained from water yam (Dioscorea alata) sample on addition of few drops of iodine solution gave a blue-black colouration. This confirmed that the tested sample is mainly starch.

\section{(b) Hydrolysed filtrate obtained}

The hydrolysed filtrate /fermentable sugar obtained from water yam (Dioscorea alata) when tested with Fehling`s solution gave a redbrown precipitate. This showed that the hydrolysed filtrate was a reducing sugar (mostly D-glucose).

\section{(c) pH of hydrolysed filtrate obtained}

After hydrolysis, the fermentable sugar was found to be too acidic ( $\mathrm{pH}$ 1.6), thus the $\mathrm{pH}$ was adjusted to $\mathrm{pH} 4.7$, since the yeast (Saccharomyces calsbergensis) used for this study is active between $\mathrm{pH} 4.50$ to 5.00. This is very close to $\mathrm{pH} 5.0$ reported by [9] to be slightly acidic condition suitable for the action of fermenting microorganism.

\section{(d) Boiling point for ethanol obtained}

The boiling point for ethanol obtained from water yam (Dioscorea alata) was $80{ }^{\circ} \mathrm{C}$. This is higher than the boiling point of $78.3{ }^{\circ} \mathrm{C}$ reported by [12]. The ethanol obtained after distillation is an azeotropic mixture and its boiling point should be higher than $78.3{ }^{\circ} \mathrm{C}$ [12].

\section{(e) Specific Gravity}

The specific gravity for ethanol obtained from water yam (Dioscorea alata) was 0.847 . This is higher than the specific gravity of 0.789 reported by [12]. The ethanol obtained after distillation is an azeotropic mixture and should be higher than 0.789 [12].

\section{(f) Viability Studies}

Calculation on viability aspect of the study is found necessary, since one of the objectives of the study was to find out the viability of a small-scale ethanol production industry. The viability studies were calculated as:

(i) Total mass of water yam starch obtained $=1,777.00 \mathrm{~g}$

(ii) Mass used for this study $=100 \mathrm{~g}$

After fermentation and distillation for every $100 \mathrm{~g}$ of water yam starch hydrolysed $375 \mathrm{~mL}$ of ethanol was obtained. If $100 \mathrm{~g}$ of starch gives $375 \mathrm{~mL}$. The fermentation of 1 ton $\left(10^{6}\right.$ g) of starch which results to the use of $10^{6} \mathrm{~g}$ milled water yam starch will give

$\frac{375 \mathrm{~mL}}{100 \mathrm{~g}} \times 10^{6} \mathrm{~g}$

$=3.75 \times 10^{6} \mathrm{~mL}=3.8 \times 10^{6} \mathrm{~mL}$

$=3.8 \times 10^{3}$ litres.

This shows that if a small-scale industry can be able to handle 1 tonne ( $10^{6}$ grammes) of starch in a month invariably $3.8 \times 10^{3}$ litres of ethanol will be produced by such industry.

Fermentation process was the method adopted in this study, since when alcohol is being manufactured by fermentation we can make use of any of the sources of carbohydrates, such as sugarcane, cassava, grains among others as raw materials and moreso, to achieve high conversion efficiency of sugar to alcohol [13, 14].

Acidic hydrolysis using dilute $\mathrm{HCl}$ was used to convert the starch obtained from water yam (Dioscorea alata) into fermentable sugar and this took about 3 hours. In comparison to enzymatic hydrolysis which will take about 3 day, acidic hydrolysis was found to produce the fermentable sugar in shorter times. 


\section{CONCLUSION}

From the foregoing water yam (Dioscorea alata) which is of low cost and not mostly consumed like other varieties is identified in the study as a good raw material for production of ethanol. Indigenous production of ethanol is economically viable. This will save the country from a lot of money that is being spent annually on the importation of ethanol and it will also provide job opportunity for unemployed citizens.

Table 1: Physico-chemical parameters of starch sample from water yam (Dioscorea alata).

\begin{tabular}{l|l}
\hline Parameters & Values \\
\hline \% Moisture content & 10.80 \\
Starch (Iodine test) & Positive \\
Reducing Sugar (Fehling's test) & Positive \\
pH for hydrolysed filtrate & 1.6 \\
pH for fermentable sugar & 4.7 \\
Volume of fermentable liquor used for fermentation & $595 \mathrm{~mL}$ \\
Volume of ethanol obtained & $300 \mathrm{~mL}$ \\
Boiling point for ethanol obtained & $80^{\circ} \mathrm{C}$ \\
Specific gravity for ethanol obtained & 0.847 \\
\hline
\end{tabular}

\section{REFERENCES}

1. B. C. Akin-Osanaiye, H. C. Nzeibe and A. S. Agbaji (2008). Ethanol production from Carica

papaya (pawpaw) fruit waste. Asian Journal of Biochemistry, 3 (3): 188-193.

2. V. Reddy (2007). Production of ethanol from mango (Mangifera indica $\mathrm{L}$ ) fruit juice fermentation. Research Journal of Microbiology, 2 (10): 763-769.

3. A. Roger, R. J. John and F. W. Charles (1979). Laboratory Experiments in Organic Chemistry. J. Chem. Educ.: 57.

4, L. Michael and W. Guy (1982). Advancing Chemistry textbook (Oxford University press): 586.

5. O. C. Aworh (2010). Food Technology and National Development: A Global Perspective. In University of Ibadan Inaugural lecture (2010) Ibadan University Press, publishing house, University of Ibadan Nigeria: 28-42.

6. B. Haynes (1966). Qualitative Organic analysis. $2^{\text {nd }}$ Edition; 46-47.

7. C. Dumazert (1950). Acid hydrolysis and Elementary analysis of starch and of Glycogen. Bull Soc. Chim. Bio., 32: 988-997.

8. H. S. Carl (1992). The extra ordinary chemistry of ordinary things: $388-390$.
9. M. M. Adeyemi, R. S. Olatubosun, O. A. Babarinde and P. E. Omale (2019).Comparative study of bioethanol production from wheat straw and rice straw. $J$. Chem. Soc. Nigeria. 44(2): 315-324.

10. A, Sapkota (2020). Fehling's Test: Definition, Principle, Procedure, Result and uses. Available online (18 ${ }^{\text {th }}$, Jan. 2021) at https://microbenotes.com/fehlings-test/.

11. NAL USDA (2015). National Agricultural Library United States Department of Agriculture. National Nutrient Database Archived (3, March 2015) at the WaybackMachine.

12. M. H. William (2014). CRC Handbook of Chemistry and Physics, $95^{\text {th }}$ Edition.CRC Press LLC. Boca Raton: 3-246.

13. Z. M., Xu, P. Chi and J. G. Liu (1995). High concentration ethanol production from corn-starch by using middle temperature, cooking process. Chinese J. Biotechnol. 11(3): 228-232.

14. W. R. Abdel-Fattah, M. Fadil and P. Nigarm (2000).Isolation of thermotolerantethanologenic yeast and use of selected strains in industrial scale fermentation in Egyptian distillery. Biotechnol, Bioeng. 68(5):
531-535. 